UDC 811.111'42:316.772.2

DOI https://doi.org/10.32841/2409-1154.2021.47-1.28

\author{
Kozlova V. V., \\ Candidate of Philological Sciences, Associate Professor, \\ Senior Lecturer at the Germanic Philology Department \\ Sumy State Pedagogical University named after A. S. Makarenko
} \author{
Candidate of Philological Sciences, Associate Professor, \\ Senior Lecturer at the Germanic Philology Department \\ Sumy State Pedagogical University named after A. S. Makarenko
}

BagatskaO. $V$.

\title{
VERBAL MANIFESTATION OF MOTHER DISCOURSE PERSONALITY IN THE ENGLISH PARENTAL DISCOURSE
}

\begin{abstract}
Summary. The paper deals with verbal manifestation of mother discourse personality on lexical and syntactical language levels in the English parental discourse. The concept of mother discourse personality has been clarified then democratic and authoritarian mother discourse personality types have been singled out. The analysis of lexical-semantic and syntactic means of the democratic and authoritarian mother discourse personality types realization in the English parental discourse has been carried out. It was found out that the specificity of mother discourse personality types is stipulated by styles of interpersonal communication treated as variable characteristics of a discourse personality. It was revealed that the lexical and syntactic means that mark the democratic mother discourse personality type include affectionate address forms, a first-person plural pronoun, positive-evaluative adjectives, simple narrative sentences, interrogative structures with volition verbs and modal verbs, elliptical sentences employed for respect, support, tolerance and compromise demonstration. Special attention is focused on the structural elements of evaluative judgments that constitute an adjective with a noun combination, a verb with an adverb combination, an adverb with an adjective combination, predicative evaluative constructions. Explicit and implicit forms of the authoritarian mother discourse personality realization are considered. The analysis of the lexical and syntactic means that implement explicit realization of the authoritarian mother discourse personality makes it possible to single out the basic structural and semantic types of statements that include affirmative, negative and imperative constructions of egocentric, generalizing, evaluative and compelling nature. Implicit realization of the authoritarian mother discourse personality presupposes the use of verbal means of manipulation. Differences in addressing forms utilized by the democratic and authoritarian mother discourse personalities are distinguished and analysed. This paper aims to compensate for the lacunae that are currently present in the field of the English parental discourse study in terms of verbal implementation of discourse personality types.

Key words: democratic mother discourse personality, authoritarian mother discourse personality, explicit realization, implicit realization, verbal markers, lexical means, syntactic means, English parental discourse.
\end{abstract}

Problem statement. The current stage of linguistics is characterized by the expansion of traditional research limits with increased interest in human factor that presupposes interpretation of linguistic phenomena in terms of communicative and discursive approach. The introduction of the language personality in the centre of modern discourse studies predetermines the necessity to consider the realities of their discursive activity, giving rise to a new phenomenon - discourse personality. They summarize the features of verbal, non-verbal behaviour and communicative-cognitive activity of individuals, as well as a combination of their sociopsychological characteristics. Since discourse personalities find their realization in a variety of discourses, the specificity of a mother discourse personality is worth regarding in the framework of the English parental discourse.

Analysis of the recent research and investigations. Discourse personality can be defined as a personality, that operates in the continuous communicative space and is apt to use and interpret along with a language code other semiotic codes depending on the type of discourse relations he is involved in certain moments of communication. The concept of a discourse personality refers to individual abilities of a language personality to react flexibly on discourse surroundings, taking into account all means of language and non-language character that are components of a communicative process [1, p. 127]. Recently researchers have shown an increased interest in language personality interpretation and characterization. A significant place in their works is occupied by the study of communicative and cognitive peculiarities of language personalities with regard to their extralinguistic features [2-6]. Along with this, however, there is increasing concern over the problem of determination and functioning of discourse personality that is widely tackled in explorations of domestic and foreign scholars. The researchers focus on discourse personality types and precise study of their particularities in institutional and non-institutional discourses thus scrutinizing various approaches to the description of personality types and their aspects of analyses [7], investigating peculiarities of the discursive personality communicative activity with regard to the role of nonverbal components in the communicative process [8], observing discursive personality's social roles [9], examining typological and communicative features of a discourse identity of the fool-wisecracker [10], analysing specificity of verbal, nonverbal, and superverbal communicative components applied by an authoritarian discursive personality of a child [11], fulfilling the complex investigation of academic discourse personality types [12]. However, too little attention has been paid to verbal behaviour of discourse personalities in the English parental discourse. This 
indicates a need to carry out in-depth analysis of verbal means involved in the realization of discourse personalities typical of English parental discourse, the mother discourse personality in particular.

The objectives. The paper is aimed at investigating verbal manifestation of the mother discourse personality in English parental discourse with emphases on lexical and syntactic language means democratic and authoritarian mother discourse personality types employ.

The body of the paper. The English parental discourse is defined as a personality-oriented interaction in the domestic sphere where participants - parents and their children realize their asymmetric status roles [13]. Parental discourse presents unofficial intellectual and emotional communication of participants that are characterized by asymmetry of status, role and age parameters and have a general thesaurus due to common retrospective and perspective life experience, use spoken language marked by spontaneity and unfixed forms of expression. The generalized images of parents fulfilling socialization intentions in the process of purposeful speech influence are viewed as parental discourse personalities that represent father and mother discourse personalities correspondently. The image of mother is associated with the formation of the mentality as a certain way of thinking, which is psychogenetically and linguistically formed from childhood. A mother provides her child with information about the world around him, forms a kind of archive, which later turns into a world of feelings and relationships. The mother creates the spiritual and emotional foundation of the personality, sets the spiritual algorithm of all subsequent life, transmits social norms and fixes them in the child's mind, conveying cultural values as a result of intimate, physical contact between mother and child [14, p. 213]. Mother discourse personality reveals herself during the communicative interaction with a child by a variety of verbal and nonverbal means. Due to socio-status modelling of a discourse personality, it is possible to contrast stable and variable characteristics (status and situationalrole). The former include biological and social indices, the latter positional, emotional, situational indices (for example, the person who orders, responds to the interrogation) $[15, \mathrm{p}$. 30]. Theoretical analysis of psychological and pedagogical research in the field of upbringing shows that parents use opposite styles of interpersonal communication: authoritarian-monologue and personalitydialogue. The first is based on the establishment of subject-object (authoritarian) interaction and involves the use of strict forms of orders and warnings, remarks and punishments. The second type is based on the premise that participants are always equal to each other [16]. Democratic and authoritarian styles as variable characteristics of a discourse personality give grounds for singling out democratic and authoritarian types of mother discourse personality in the frame of the English parental discourse. The democratic mother discourse personality strives for partner interaction with a child, while the authoritarian one exposes the tendency to domination that is illustrated by the choice of corresponding verbal means on lexical and syntactical levels.

Forms of address identify emotional and psychological attitude of the discourse personality. The democratic mother discourse personality creates a favourable tone of communication, establishes emotional contact, demonstrates support and compassion using at the lexical level the affectionate address forms for child nominations: "Mummy?" "Yes, love". "Can I have a swimming party?" "Of course, sweetheart". (A. Pearson, P.148). She also employs the personal pronoun we, which conveys the sense of joint identification with the child and indicates the desire for cooperation: "Mommy?" "Yeah". "Do you think Simone is making a mistake?" "Yeah. A huge mistake". "What should we do?" "What can we do? We're just going to love her, accept her. She's family. And her baby will be family" (A. Lamott, P. 290). In this situation mother does not separate herself from her daughter supporting her in making crucial decisions.

The democratic mother discourse personality treats her child as an equal partner and prefers positive assessments. Using positiveevaluative adjectives of explicit semantics beautiful, bright, good the mother expresses concisely and straightforwardly a positive perception and evaluation of the child. Syntactic means of evaluative judgments are represented by simple narrative sentences, characterized by a set of structural elements necessary for the explication of the evaluative meaning. The main structural types are:

a) the combination of an adjective with a noun: "You are a good boy, a good son, only - only don't do anything foolish" (B. Plain, P. 25).

b) the combination of a verb with an adverb: "Oh baby, you look so good!" (D. Steel: Full circle, P. 147). "Abby, you look fantastic,"(C. Kelly, P. 591).

c) predicative evaluative constructions: "You did the right thing," Madge nodded. Madge swept him to her and hugged him tight. "You'll go far in life, son," she said. "I just know you will." "I always try to do my best as you taught me to, Ma."

"That's right. Do your best in life and that way you'll succeed" (E. Blair, P. 25).

d) the combination of an adverb with an adjective, where the adverb is an intensifier of assessment: "You are too bright. Don't let one section of the course mess up your chances" (C. Kelly, P. 428).

The democratic mother discourse personality always gives her child the freedom of choice. Utilizing interrogative structures with volition verbs she demonstrates the intention not to impose her will on the child: "Do you want to talk about it?" Elizabeth asked delicately (A. Lamott, P. 92). The democratic mother discourse personality displays equality with the child and respects his personal space. She neglects her higher social status and asks for permission using modal verbs in interrogative structures: Katharine went to his door, knocked softly, then opened it a crack. "Michael? May I come in??" When there was no answer, she spoke again. "Tell you what. I'll forgive you for being late if you'll forgive me for forgetting that you made the team today. I'm really sorry I yelled at you." (J. Saul, $P$. 106) Affirmative sentences with personal subject pronoun indicate willingness and readiness of the mother to admit her faults. The mother tries to restore the relationship with her son asking for permission and apologizing for shouting at him.

Another aspect of the democratic mother discourse personality manifestation concerns the role of a friend she takes on when delicately suggesting advice on an intimate issue, as a child lacks knowledge and experience: "Oh, darling. Listen. You know" "Please, Mom," said Rosie wearily. "Please don't give us a little talk." "I just want Simone to know, and you too, that if and when you need to talk to someone about-birth control, then that someone can be me" (A. Lamott, P. 173). The metacommunicative operators are utilized by the speaker to initiate interaction, she employs the modality of necessity and possibility not economizing on language means.

The use of elliptical sentences as verbal markers of the democratic mother discourse personality speech behaviour is stipulated by 
common knowledge, spiritual closeness and increased positive emotionality typical of interaction between mother and child in the parental discourse: "Morning." - Beth turned around and saw her daughter leaning against the doorway to the kitchen. "Morning, yourself. It's early for you." She glanced at the clock on the wall and raised her eyebrows. "Barely nine and on a Saturday, too. Whatever is the world coming to?" (S. Mallery, P. 39). The choice of elliptical constructions in the given communicative situation is an indicator of informality of relations that accounts for nonobservance of grammatical rules.

The concept of authoritarianism refers to the domination of one person who requires and achieves unconditional obedience, execution of their orders and directives and uses a rigid, strongwilled style of exercising power. It is based on the psychological traits of authoritarian personalities as well as their status prevalence and is realised in explicit and implicit forms of authoritarian communicative behaviour. [5, p. 5]. Authoritarian mother discourse personality exercises her parental rights to regulate, control and unconditionally impose opinion due to her status, role and age marked superiority thus exerting educational speech influence in the parental discourse. Explicit realization of the authoritarian mother discourse personality behaviour presupposes the use of verbal means of the category of negation, the category of evaluation and the category of modality, represented by the modality of compulsion, voluntary modality, modality of obligation, modality of possibility and necessity.

The main structural and semantic types of statements that provide the explicit realization of the authoritarian mother discourse personality are affirmative, negative and imperative constructions, among which we distinguish constructions of egocentric, generalizing, evaluative and compelling nature.

Egocentric constructions which contain personal and possessive pronouns as well as voluntative modality verbs convey the concept of authoritarian mother discourse personality self-centeredness: "I want you to look at me when I'm talking" (A. Lamott, P. 14).

Generalizing constructions are employed by the authoritarian mother discourse personality for lecturing and moralizing. The effect of generalization is created by means of a categorization lexeme: "Men and women can't be friends" (D. Stee, P. 148).

Evaluative affirmative constructions with lexical means of negative-evaluative semantics - nouns, adjectives, verbs and interrogative negative constructions are used to implement reprimand, condemn and accusation. Emotive language means: repetition of the pronoun of the second person singular you, indefinite pronoun anything, negative adjectives are used to present a critical assessment, thus creating a negative image of her child: "You are talking rubbish. You are disobedient and ungrateful. You haven'teven matriculated. You are unskilled in anything" (H. Forrester, P. 113). There is a general trend of increasing concentration and variability of negative verbal means of evaluation and intensification of critical judgement of a child authoritarian mother discourse personality displays by the use of adjectives (disobedient, ungrateful unskilled), verbs (insult, hurt, break, forget), negative pronoun (never).

Constructions of compel are represented by negative presentcontinuous, negative imperative and affirmative structures with ban nomination. The authoritarian mother discourse personality realizes her intentions of prohibition utilizing lexical and syntactical means of the category of negation. In present-continuous constructions the combination of the negative participle with the verbs of permission or motion explicates the restriction of the addressee's freedom of action with regard to certain conditions: "You are not leaving the table until you do" (C. Kelly, P. 432). "I'm not letting you out of this room until you tell me" (D. Steel: The Gift, P. 90). In negative imperative constructions grammatical negation contributes to the categoricalness of statements and ensures the unambiguity of their interpretation: "Don't talk to me like that" (D. Steel, $P$. 210). In affirmative constructions, the nomination of prohibition is provided by lexical units of negative semantics: "You're grounded forever," Elizabeth managed to say. (A. Lamott, P. 283).

Authoritarian mother discourse personality always dominates and controls. To emphasize her own dominant position she uses concise imperative constructions: "I said upstairs, Franny. Don't argue, just go" (M. Stolz). Mother orders not giving her child the chance of refuse. To retain total control the authoritarian mother discourse personality seeks for information about her son's personal affairs. She initiates communication by the special question and uses elliptical interrogative constructions to clarify details of a particular event: "Where have you been?" his mother asked in stern tones when he got in. She had been waiting up for him in the kitchen. "Studying with some friends," he answered, looking nervous. "What friends?" She knew almost all of them, "particularly now that she was teaching at the high school. "Who? Their names" (D. Steel: The Gift P. 190). The authoritarian mother discourse personality excerpts control over interaction and interrupts it abruptly and harshly ignoring the interests of the interlocutor: "We'll talk about it another time, Tana" (D. Steel: Full Circle, P.47). To demonstrate dominance she informs about it impolitely using imperative: "Get out of my sight" (H. Forrester, P. 113).

Implicit realization of the authoritarian mother discourse personality behaviour presupposes manipulation that involves "indirect influence based on automatisms and stereotypes in order to change the guidelines and motives of the addressee's behaviour" [17]. The authoritarian mother discourse personality persuades her child by focusing on interests and needs of the latter, but does not meet them, only uses them to satisfy her own. Mother struggles to keep control of her daughter encouraging to behave in a way that is beneficial to her (mother). By demonstrating daughter's false needs she establishes motives to attend the ball. "The ball, Tana, the ball ... I don't know if you realize it yet, but something like that is very important for a young girl, and it's not something that I could provide for you myself." "Important...? Important to whom...?" "You have no idea what something like this means." (D. Steel: Full Circle, P. 109). Verbal means of positive semantics are utilized to create the attractive image of the desired.

Addressing utilized by the authoritarian mother discourse personality identifies an increase in communicative distance and is represented by emotional-evaluative nominations and name: "If you ever do anything like this again, Christopher Foxworth, I will myself whip not only you, but Cathy, as well" (V. Andrews). The mother expresses her dissatisfaction with the son's disobedience, calls him by name and surname, makes threats she is intending to carry out.

Conclusion. These findings suggest that mother discourse personality - a generalized mother image fulfilling socialization intentions in the English parental discourse, is represented by the democratic and authoritarian discourse personality types that are specified by choice of particular lexical and syntactical language means. The results of the study of the democratic mother discourse personality verbal manifestation indicate that 
lexico-syntactic markers include affectionate address forms for child nominations, first-person plural pronoun to convey mother-child joint identification, positive-evaluative adjectives, simple narrative sentences to present favourable judgments, interrogative structures with volition verbs and modal verbs as well as elliptical sentences to display respect, support, tolerance and willingness to compromise. The evidence from the study also indicates that the authoritarian mother discourse personality takes on explicit and implicit forms of realization. Explicit realization presupposes the use of verbal means of the category of negation, the category of evaluation and the category of modality, that are represented by affirmative, negative and imperative constructions of egocentric, generalizing, evaluative and compelling nature. To maintain control and dominance she utilizes imperative and elliptical interrogative constructions. Implicit realization of the authoritarian mother discourse personality behaviour presupposes manipulation.

Further research in the framework of the parental discourse personality types can be focused on the study of strategies and tactics the democratic and authoritarian discourse personalities utilize with regard to situational context, gender and age factors of interlocutors in synchronic and diachronic perspectives.

\section{References:}

1. Солощук Л.В. Вербальні і невербальні компоненти комунікації в англомовному дискурсі : монографія. Харків : Константа, 2006. $300 \mathrm{c}$.

2. Бондаренко Я.А. Дискурс акцентуйованих мовних особистостей: комунікативно-когнітивний аспект (на матеріалі персонажного мовлення в сучасній американській художній прозі) : автореф. дис. ... канд. філол. наук : 10.02.04. Київ, 2002. 248 с.

3. Гайдаенко А.В. Лексикон персонажной харизматической язіковой личности как отражение ее концептуальной картины мира. Культура народов Причерноморья. 2003. № 37.С. 30-32.

4. Ємельянова О.В. Мовленнєве вираження статусу адресата в англомовному художньому дискурсі закоханих : автореф. дис. ... канд. філол. наук : 10.02.04. Харків, 2006. 20 с.

5. Крючкова П.Г. Авторитарний дискурс (на матеріалі сучасної англійської мови) : автореф. дис. ... канд. філол. наук : 10.02.04. Київ, 2003. 21 с.

6. Ницполь В.І. Мовна особистість персонажа серійного вбивці (на матеріалі американської прози XX століття) : дис. ... канд. філол. наук : 10.02.04 / Прикарпат. нац. ун-т. імені Василя Стефаника; Львів. нац. ун-т імені Івана Франка. Львів, Івано-Франківськ, 2018. URL: https://www.lnu.edu.ua/wp-content/uploads/2019/04/ dis_nytspol.pdf (дата звернення 9.02.2021).

7. Karasik V.I., Gillespieb D. Discourse Personality Types. Procedia Social and Behavioral Sciences 2014. 154. P. 23-29 DOI: 10.1016/j. sbspro.2014.10.106.

8. Солощук Л.В. Дискурсивна особистість у світлі теорії полікодовості комунікативного процесу. Записки з романо-германської філологіï. 2015. № 1 (34). С. 160-167.

9. Скриннік Ю.С. Дискурсивна варіативність вербальної та невербальної поведінки мовців при зміні соціальних ролей (на матеріалі англійської мови) : дис. ... канд. філол. Наук : 10.02.04 / Харк. нац. ун-т імені В.Н. Каразіна. Харків, 2019. URL: https:/core.ac.uk/ download/pdf/201485561.pdf (дата звернення 9.02.2021).

10. Тарасова С.О. Дискурсивна особистість дурня-сміхача у карнавальному просторі США та Великої Британії : дис. ... канд. філол. наук : 10.02.04 / Харк. нац. ун-т імені В.Н. Каразіна. Харків, 2018. URL: http://dspace.univer.kharkov.ua/handle/123456789/14408 (дата звернення 26.01.2021).
11. Пахаренко А.В. Дитина як авторитарна дискурсивна особистість (на матеріалі сучасної англійської мови) : дис. ... канд. філол. наук : 10.02.04 / Харк. нац. ун-т імені В.Н. Каразіна. Харків, 2020. 260 с.

12. Aliyeva E.M., Aliyeva S.A. Academic discourse personality British Journal of English Linguistics. 2019. Vol. 7. № 5. P. 50-61. URL: https://www.eajournals.org/journals/british-journal-of-englishlinguistics-bjel/vol-7-issue-5-november-2019/academic-discoursepersonality (дата звернення 2.02.2021).

13. Козлова В.В. Реалізація виховного впливу в англомовному парентальному дискурсі: структурно-семантичний та прагматичний аспекти : дис. ... канд. філол. наук : 10.02.04 / Харк. нац. ун-т імені В.Н. Каразіна. Харків, 2012. 219 с.

14. Хименко С.А. Аналіз особливостей мовленнєвої домінанти мовної особистості матері (на матеріалі сучасної англійської мови). Вісник Житомир. держ. ун-ту імені I. Франка. 2005. № 23. C. 211-214.

15. Карасик В.И. Речевое поведение и типы языковых личностей. Массовая культура на рубеже ХІХ и ХХ веков: Человек и его дискурс. 2003. С. 24-45.

16. Горецька О.В. Оптимізація спілкування батьків з дітьми дошкільного віку. Розвиток особистості в сучасному освітньому проcторі : колективна монографія / за заг. ред. О.В. Горецької. Донецьк, 2013. С. 95-114.

17. Седов К.Ф. Дискурс как суггестия : Иррациональное воздействие в межличностном общении. Москва : Лабиринт, 2011. 336 с.

\section{Sources of illustrative material:}

1. Andrews V. Flowers in the Attic: a novel. 1979. 218 p.

2. Blair E. The Water Medows. Bantan Books : London, 1992. 575 p.

3. Forrester H. Liverpool Miss. Fontana Collins, 1988. 290 p.

4. Kelly C. Someone Like You. Harper Publishers, 2001. 677 p.

5. Lamott A. Crooked Little Heart. Anchor Books Doubleday, 1998. 327 p.

6. Mallery S. Beth and the Bachelor. Silhouette Books, 2000.251 p.

7. Pearson A. I Don't Know How She Does It. Vintage, 2003. 357 p.

8. Plain B. Homecoming. Hodder \& Stoughton Ltd., 1998. 212 p.

9. Saul J. The Presence. Fawcett Crest : New York, 1997. 417 p.

10. Steel D. Full Circle. A Dell Book : New York, 1989. 447 p.

11. Steel D. The Gift . Corgi Books, 1995. 319 p.

12. Stolz M. The Noonday Girls. 1993. 182 p.

Козлова В. В., Багацька О. В. Вербальна репрезентації дискурсивної особистості матері в англомовному парентальному дискурсі

Анотація. У статті досліджується питання вербальної репрезентації дискурсивної особистості матері в англомовному парентальному дискурсі засобами лексичного та синтаксичного мовних рівнів. Уточнено поняття дискурсивної особистості матері та виокремлено демократичний та авторитарний ïi типи. Проведено аналіз лексико-семантичних i синтаксичних засобів реалізації демократичного й авторитарного типів дискурсивної особистості матері в англомовному парентальному дискурсі. 3'ясовано, що специфіка типів дискурсивної особистості матері зумовлена стилями міжособистісного спілкування, що трактуються як змінні характеристики дискурсної особистості. Було виявлено, що лексико-синтаксичні маркери демократичної дискурсивної особистості матері представлені пестливими номінаціями дитини, займенником першої особи множини, позитивно-оцінними прикметниками, простими розповідними реченнями, питальними структурами 3 волітивними та модальними дієсловами, еліптичними реченнями, що застосовуються задля демонстрації поваги, підтримки, толерантності та готовності до компромісу. Особлива увага фокусується на аналізі структурних 
елементів оціночних суджень, що утворені поєднанням прикметника з іменником, дієслова із прислівником, прислівником із прикметником, предикативними оціночними конструкціями. Розглянуто також експліцитні й імпліцитні форми реалізації авторитарної дискурсивної особистості матері. Аналіз лексико-синтаксичних засобів, що забезпечують реалізацію експліцитної авторитарності дискурсивної особистості матері, дозволяє виділити основні структурно-семантичні типи висловлювань, які репрезентовані стверджувальними, заперечними й імперативними конструкціями егоцентричного, узагальнюючого, оціночного та директивного характеру. Імпліцитна реалізація авторитарної дискурсивної особистості матері передбачає використання вербальних засобів маніпуляції. Виділено та проаналізовано відмінності у виборі форм звертання, що використовуються демократичними й авторитарними дискурсивними особистостями матері в англомовному парентальному дискурсі. Публікація покликана компенсувати лакуни, які наявні сьогодні у сфері дослідження англомовного парентального дискурсу з погляду мовної реалізації типів дискурсивних особистостей.

Ключові слова: демократична дискурсивна особистість матері, авторитарна дискурсивна особистість матері, експліцитна реалізація, імпліцитна реалізація, вербальні маркери, лексичні засоби, синтаксичні засоби, англомовний парентальний дискурс. 